\title{
Risk of Airborne Infection and Transmission-based Precautions in Dental Setting
}

\author{
Kurinji A Ratnakaran ${ }^{1}$, Hrudi S Sahoo ${ }^{2}$
}

\begin{abstract}
In the current scenario of constant emergence and re-emergence of infectious diseases around the world, the dental fraternity must be well aware of the basic principles that govern infection prevention, and control to ensure preparedness and safe dental practice. Most dental procedures involve the use of one or more devices that generate spatter and aerosol. The dental aerosols may carry water, saliva, mucous, microorganisms, debris, calculus, blood, respiratory secretion, and/or metallic trace elements from restorative materials and possess a potential risk of disease transmission through inhalation to both the dental healthcare personnel (DHCP) and patients. Standard precautions taken during routine dental practice adequately protect the dental team and patients from the direct and contact-based transmission, but these precautions may not be sufficient to prevent airborne transmission of infectious diseases. Although the limited available evidence estimates the risk of airborne transmission in a dental setting to be low, it should not be underestimated. This narrative review aims to review the quantity, characteristic features, pathogenicity of aerosols produced in the dental settings, the associated risks, and precautions to be followed.

Keywords: Aerosols, Infection control, Infections, Saliva, Virulence.

Journal of Operative Dentistry and Endodontics (2020): 10.5005/jp-journals-10047-0090
\end{abstract}

\section{INTRODUCTION}

In the year 1993, the Centers for Disease Control and Prevention (CDC) published recommended infection control practices for dentistry. It was primarily set on healthcare precedent, theoretical rationale, and expert opinion to reduce the risk of transmission of blood-borne pathogens among the dental healthcare personnel (DHCP) and patients. ${ }^{1}$ These universal precautions were based on the principle that blood and all body fluids contaminated with blood is infectious. It also mandates to assume all patients to be asymptomatic carriers of blood-borne pathogens. In the year 1996, the $C D C$ revised the above recommendations and adopted the term "standard precautions". Standard precautions apply to contact with (1) blood (2) all body fluid secretions, and excretions (except sweat), regardless of whether they contain blood, (3) nonintact skin, and (4) mucous membranes. ${ }^{1}$ Hence, these precautions stand to embrace the standard of care provided to minimize the risk of disease transmission to the DHCP and patients through pathogens in blood and other body fluids, including saliva and respiratory secretions. Airborne transmission refers to the passage of microorganisms from a source to a person through aerosols, resulting in the infection of the person with or without the consequent disease. ${ }^{2}$ Airborne transmission is categorized into three types: (1) Specific air transmission, that is, transmission caused by inhalation of aerosol particles under natural conditions [e.g., tuberculosis (TB)]; (2) Priority air transmission, that is, multiple transmission methods can cause the disease, but inhalation of aerosol particles is the primary mode (e.g., measles and chickenpox); (3) Opportunistic airborne transmission, occurs when a disease mainly spreads through contact and droplet transmission, but under certain conditions can also spread through inhalation of aerosol particle (e.g. influenza and SARS). ${ }^{3}$ The World Health Organization (WHO) and CDC does not consider opportunistic airborne transmission as airborne. ${ }^{4}$

Only a few diseases (like TB, measles, and chickenpox) are recognized as 'true' airborne infectious diseases by American CDC infection control guidelines for healthcare and the WHO. ${ }^{4}$ But

\begin{abstract}
1,2Department of Conservative Dentistry and Endodontics, Sathyabama Dental College and Hospital, Chennai, Tamil Nadu, India
\end{abstract}

Corresponding Author: Hrudi S Sahoo, Department of Conservative Dentistry and Endodontics, Sathyabama Dental College and Hospital, Chennai, Tamil Nadu, India, Phone: +91 9962938037, e-mail: hrudi21. dental@sathyabama.ac.in

How to cite this article: Ratnakaran KA, Sahoo HS. Risk of Airborne Infection and Transmission-based Precautions in Dental Setting. J Oper Dent Endod 2020;5(1):18-24.

Source of support: Nil

Conflict of interest: None

there is an increasing understanding that many other organisms like Bordetella pertussis, influenza virus, adenovirus, rhinovirus, Mycoplasma pneumoniae, coronaviruses (SARS-CoV) and (SARS-CoV 2), Group A Streptococcus and Neisseria meningitidis where their acquisition, replication and/or colonization occur in the respiratory tract may also behave as 'airborne', given a favorable environment irrespective of their primary mode of transmission. ${ }^{5}$ Reports also suggest that in a pandemic or massive, explosive outbreak situations diseases like influenza and SARS-CoV can become truly airborne. ${ }^{6,7}$ Mouth as a part of the oronasal pharynx also harbors bacteria and viruses from the nose, throat, and respiratory tract in the saliva and oral fluids. Therefore, any dental procedure that aerosolizes saliva has the potential to cause airborne contamination of the dental setting.

\section{Airborne Transmission}

Airborne transmission occurs through droplets and aerosols. Droplets are atomization of particulate liquid and solid particles when a person coughs or sneezes, or when water is converted into a fine mist through an aeration device or a shower head. ${ }^{2}$

Spatter refers to droplets usually greater than $100 \mu \mathrm{m}$ in diameter, visible to the naked eye, with sufficient mass and kinetic 
energy dropping to the floor within seconds of expulsion. They may contain infectious bacteria and viruses harbored in blood, respiratory secretions, and saliva. They are capable of transmitting disease through direct contact with exposed mucous membranes of the eye, nose, and mouth or indirectly through fomites. ${ }^{8}$ Human immunodeficiency virus (HIV) and hepatitis B (HBV) have been transmitted to healthcare workers by blood spatter. ${ }^{9}$

Aerosols are a dispersive system of suspended solid or liquid particles in gas and those aerosols that contain pathogens are considered infectious. They contain particle size ranging from 0.001 to over $100 \mu \mathrm{m} .{ }^{10}$ Many have classified these droplets based on particle size, but it is generally accepted that (i) large droplets $(>20 \mu \mathrm{m})$ that follow a more ballistic trajectory, as they are too large to follow inhalation airflow streamlines and usually associated with short-range transmission $(1 \mathrm{~m}){ }^{11}$ (ii) small droplets $(<5-10 \mu \mathrm{m})$ that follow airflow streamlines and remain suspended for longer periods, (iii) intermediate droplets $(10-20 \mu \mathrm{m})$ possess properties of both small and large droplets, settle faster than particles $<10$ $\mu \mathrm{m}$, and potentially carry a smaller infectious dose compared to the large droplets. ${ }^{8}$

\section{Fate of Spatter and Aerosol}

The threshold size of large droplet fallout is $60-80 \mu \mathrm{m}$. Some exhaled large droplets (initial sizes of $<60 \mu \mathrm{m}$ ) involved in droplet transmission can remain suspended in the air, but for a much smaller period than the air-change time scale of one hour in a typical room. Aerosols (particles $<50 \mu \mathrm{m}$ in diameter) are considered the greatest threat in airborne transmission diseases in dentistry. These can stay airborne and have the potential to enter respiratory passages around ill-fitted masks. ${ }^{8}$

A droplet nucleus is the airborne residue of a potentially infectious (microorganism bearing) spatter from which most of the liquid has evaporated. ${ }^{12}$ Droplets that are less than $60 \mu \mathrm{m}$ are more likely to evaporate, forming droplet nuclei $(<10 \mu \mathrm{m})$ before hitting an object in its trajectory, remain airborne, and participate in long-range transmission. ${ }^{2}$ In dry conditions, droplets evaporate quickly and can remain suspended in the air for a long time. There is evidence showing that the relative humidity, size distribution, and travel distances of droplet nuclei can significantly influence the risk of transmission of infectious diseases in the indoor environment. Early epidemiological and simulation studies of specific diseases have shown the risk range of droplet transmission is within 3 feet $(0.9144 \mathrm{~m})$ around the patient, ${ }^{13,14}$ but SARS investigations during the 2003 outbreak showed that the spread of droplets from SARS patients was even greater than 6 feet $(1.8288 \mathrm{~m}) .{ }^{15}$ Droplet nuclei are implicated in the transmission of TB, SARS, measles, and herpes. ${ }^{4}$

Of particular interest are aerosol particles in the 0.5-10 $\mu \mathrm{m}$ diameter range (median particle diameter $5 \mu \mathrm{m}$ ). It is important to understand the role of the droplet size in disease transmission, particles of $<5 \mu \mathrm{m}$ can readily penetrate the airway down to the alveolar space and are highly capable of initiating a lower respiratory tract (LRT) infection. Particles of diameter around 10 $\mu \mathrm{m}$ can penetrate up to the glottis, beyond which the penetrability diminishes; particles $>20 \mu \mathrm{m}$ will probably impact respiratory epithelial mucosal surfaces or be trapped by cilia before reaching the LRT. ${ }^{10}$ Older experimental studies and some recent field observations of influenza cases consistently associate aerosol-based transmission with a more severe form of the illness. ${ }^{16-18}$ Therefore, particles of size $<10 \mu \mathrm{m}$ are of concern, for their significant qualitative differences including the prolonged suspension time,

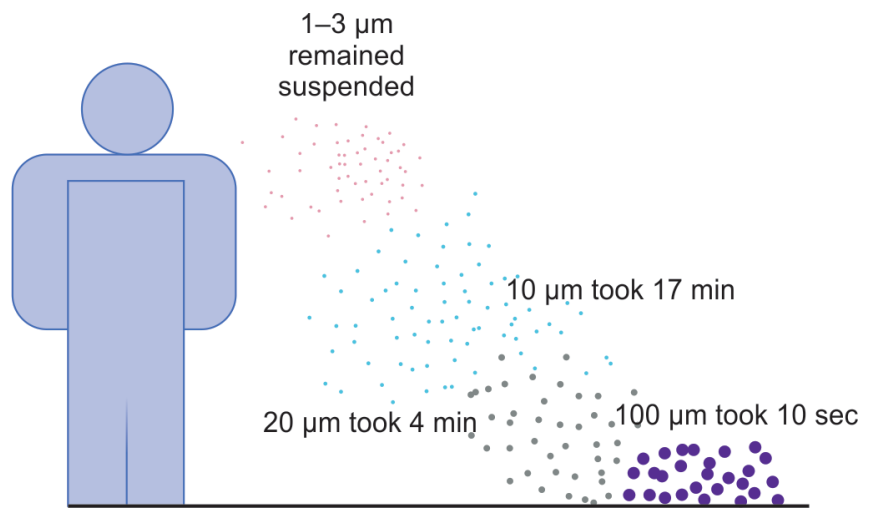

Fig. 1: Airborne particle size and time taken to fall on the floor from a height of $3 \mathrm{~m}$

penetrability into the airways, and specific requirements for personal protective equipment (PPE).

Knight estimated the time taken for the particles of various diameters to fall $3 \mathrm{~m} .{ }^{10}$ Particles of diameter: $1-3 \mu \mathrm{m}$ remained suspended almost indefinitely; $10 \mu \mathrm{m}$ took 17 minutes; $20 \mu \mathrm{m}$ took 4 minutes, and $100 \mu \mathrm{m}$ took 10 seconds to fall to the floor (Fig. 1). ${ }^{19}$ "Naked" viruses, bacteria, and fungal spores (i.e., without associated water, mucus, or pus droplets) range in approximate size from 0.02 to $0.3 \mu \mathrm{m}$, from 5 to $100 \mu \mathrm{m}$, and from 1 to $10 \mu \mathrm{m}$, respectively. ${ }^{20}$ The amount of solid matter in a droplet ultimately determines its minimal size limit and infectivity. Infectious agents disseminated in mucus or saliva remain viable for a longer duration of time.

\section{Risk of Airborne Transmission in Dental Setting}

The microbial load of dental aerosol may vary widely depending upon its source. The common sources are the operating site (patient's saliva, respiratory secretions, plaque, and tooth), water from the dental unit water lines (DUWLs), and/or contaminated dental instruments and devices. Qualitative and quantitative analysis of the makeup of dental aerosols would be extremely difficult, and the composition of aerosols probably varies with each patient and operative site. However, it is reasonable to suppose that components of saliva, nasopharyngeal secretions, plaque, blood, tooth components, and any material used in the dental procedure, like abrasives for air polishing and air abrasion, all are present in dental aerosols.

Micik et al. performed a series of interesting experiments to study the dynamics of dental aerobiology in the late 1960s and 1970s, recognizing the relevance of particles consisting of or conveying microorganisms, irritants, allergens, or other toxic substances that can be atomized into the air during the dental procedures as a potential source of disease transmission. 8,21,22 The results of their research showed that the dental procedures incorporating the use of water sprays or rotary instruments generated aerosols with significantly greater bacterial count (Box 1). ${ }^{21}$

The splatter landed six inches to four feet from the mouth of the patient and easily encompassed the area occupied by the dentist and his assistant. ${ }^{23,24}$ An experiment using dye tracer demonstrated the spatter settled immediately and visible mist usually composed of droplets over $50 \mu \mathrm{m}$, gradually settled in less than one minute, within a few feet of their origin. The finest aerosols were invisible and traveled over 2 feet or more and continued to settle for at least 10 minutes despite air exchange rates of one every 4 minutes. The fluorescent dye not only coated the surfaces of the operator's 


\begin{tabular}{|c|c|c|}
\hline \multicolumn{3}{|c|}{ Box 1: Aerosol generating activities } \\
\hline \multirow[t]{3}{*}{ Patient activities } & Sneezing & $\begin{array}{l}\text { Produce } 40,000 \text { drop- } \\
\text { lets projected to sev- } \\
\text { eral meters which can } \\
\text { evaporate to produce } \\
\text { droplets of } 0.5-12 \mu \mathrm{m} \\
\text { in diameter }\end{array}$ \\
\hline & Coughing & $\begin{array}{l}\text { Produce about 3,000 } \\
\text { droplet nuclei }\end{array}$ \\
\hline & Talking & $\begin{array}{l}5 \text { minutes of talking } \\
\text { approximate one } \\
\text { cough }^{26}\end{array}$ \\
\hline \multirow[t]{7}{*}{ Dental procedures } & Polishing with cups & Similar to coughing ${ }^{21}$ \\
\hline & Air spray & \\
\hline & $\begin{array}{l}\text { Air turbine } \\
\text { handpiece without } \\
\text { water coolant }\end{array}$ & \\
\hline & $\begin{array}{l}\text { Air turbine hand- } \\
\text { piece with water } \\
\text { coolant }\end{array}$ & $\begin{array}{l}\text { An air turbine } \\
\text { handpiece, when used } \\
\text { with air-water spray } \\
\text { coolant, atomized } \\
20 \text { times greater } \\
\text { numbers of bacteria } \\
\text { than with air spray } \\
\text { alone }^{21}\end{array}$ \\
\hline & Ultrasonic scaling & Amounts to a \\
\hline & $\begin{array}{l}\text { Polishing with a } \\
\text { bristle brush }\end{array}$ & $\begin{array}{l}\text { maximum of aerosol } \\
\text { generation } 21,23,24\end{array}$ \\
\hline & Air-water spray & \\
\hline
\end{tabular}

arms, lower neck region, chest, and face shield but was detected in the nose of the operator too, through a single-layered face mask behind the face shields. ${ }^{24}$

Dental aerosol experiments were conducted in various dental setups. It was noticed that in a single closed or multiple chaired clinic, the aerosol required 10 minutes $^{24}$ to 2 hours to clear away from the operatory respectively, depending on the air changes..$^{27,28}$ The aerosol contaminated the whole room in a single closed operatory ${ }^{29}$ and spread to areas distant from the treatment zone in multiple chaired open layout setup. .7,28,30 $^{2}$

Contaminated instruments and high-speed devices are the major sources of cross infection in dental settings. Viable virus was recovered from internal flushing of handpieces regardless of the antiretraction valve feature. ${ }^{31-33}$ Blood-borne pathogens are rarely found in the oral cavity and when they do arise, they are present in low concentrations. A Lancet clinical trial clearly showed detectable levels of HIV and HBV, viral DNA recovered from the internal parts of the devices, and the connected air/water lines after treating known infected cases. ${ }^{32}$ Many researchers demonstrated a significant increase in the quantity of airborne bacterial count during the dental procedures. ${ }^{24,34-36}$ But most of them fail to identify, differentiate, and determine the pathogenicity of the dental aerosols owing to the inherent limitations of the methods used.

There is some evidence for greater prevalence of respiratory diseases among dentists. ${ }^{37-39}$ Elevated antibody levels in dental workers ${ }^{40}$ and a greater risk among susceptible patient groups ${ }^{41}$ for Legionella pneumophila, has been documented. A study by Polednik revealed that dental drilling and grinding of restorations generated 16 times higher levels of the submicron sized particle with significantly elevated concentration of potentially toxic trace elements. This could pose serious health hazards to the dental team and patients on repeated exposures. ${ }^{42}$

\section{Methods for Reducing Airborne Contamination in a Dental Setting}

It is pertinent to meticulously follow the standard precautions, ensure strict adherence to hand hygiene and cough etiquette, disinfection and sterilization of dental instruments, and environmental disinfection to mitigate the risk of droplet and contact-based transmission. Although the risk of opportunistic airborne transmission in dental setup is believed to be low, the DHCP must be capable of identifying transmission-based risk, understand the basic principles of infection control and apply the same to break the cycle of infection.

\section{Source Control}

The best way to prevent airborne transmission is to prevent the pathogen from becoming airborne. The efficiency of operating field isolation with a rubber dam in reducing the levels of bacterial aerosols has been well documented since the 1960s. ${ }^{21,43}$ Once the aerosol is disseminated from the oral cavity, properly installed highvelocity evacuation (HVE) during the dental procedures can be of a great value in eliminating most airborne particles..$^{21,44,45}$ But it is also important to note that the HVE will not attract or reduce the spatter and large droplets from the operating field as they have higher mass and kinetic energy to resist the airflow, ${ }^{8}$ which further emphasizes the need for personal barrier and environmental disinfection. The HVE should not be released into the operatory.

Water from the DUWL makes up for most of the dental aerosol. Proper maintenance of the DUWL with a combination of commercially available micro filters, chemical treatment, and selfcontained water systems is required to meet the quality standards recommended by American Dental Association $(<500 \mathrm{CFU} / \mathrm{mL}){ }^{46}$ Contaminated patient material has been shown to enter the DUWL through devices attached to them even though all dental units marketed post-1980 are prefitted with an antiretraction valve. ${ }^{31,32}$ Therefore, it is essential to inspect water retraction periodically and add or replace antiretraction valves as and when indicated. The retraction effect is checked by observing the tip of the DUWL device coupling when the water is turned on and then off. A drop of water hanging from the tip is an indication that retraction is ineffective. Flushing of the device attached to the DUWL for 30 seconds at the beginning of the day and for 15 seconds after each patient is recommended by the CDC to limit cross-contamination. ${ }^{46}$ The addition of extremely low concentrations of chemical disinfectants like sodium hypochlorite $(0.01 \%),{ }^{47}$ povidone-iodine $(0.5 \%)$, sodium chloride $(0.05 \%)$, hydrogen peroxide $(0.03 \%)$ to the DUWL has shown to effectively reduce the viability of microorganisms contained in the aerosol. ${ }^{48}$ But their effect on handpieces and human safety has not been studied enough. High-speed devices that are attached to the DUWL must be cleaned, lubricated and heat sterilized between every use according to the manufacture's instruction.

The use of antimicrobial, preprocedural oral rinses has shown a reduction in the microbial count of dental aerosol ${ }^{49,50}$ but its role in reducing the risk of disease transmission is not well-established. Antimicrobial rinses can only affect planktonic organisms in the oral cavity and it has no effect on dental plaque, does not penetrate subgingivally, is rapidly neutralized by blood in the operating 
field, and is less likely to affect viruses and bacteria harbored in the nasopharynx. ${ }^{1}$ Yet the $\mathrm{CDC}$ recommends it as a good practice. ${ }^{51}$

\section{Personal Protective Equipment}

Standard precautions warrant the use of personal protective equipment like gloves, masks, protective eyewear, face shield, and gowns by the DHCP to protect the skin and mucosa from direct contact. Standard surgical masks would be considered an effective physical barrier against spatter and large droplets, as their size is too large to be inhaled around the sides of the mask which are not close-fitting. But, for effective protection from finer aerosol, protective eyewear with an adequate soft-tissue fit and multilayered, preformed, well-fitted face masks with higher filtration efficiency like N95 or equivalent are recommended. 1,22,24,52 The CDC also recommends respiratory protection (e.g., fit-tested, disposable $\mathrm{N}-95$ respirators) while treating infected or suspected cases of TB. ${ }^{1}$ To maximize protection, the mask must be worn at all times while the DHCP is within an aerosol generating operatory. Dental practices should have a respiratory protection program in place to train and test the fitting of respirators at least annually.

\section{Engineering Controls}

The three prerequisites for emphasizing the possibility of aerosol transmission are "closed environment", "high concentration", and "long-term exposure". Therefore, as long as one of the links is broken and the source and transmission routes are blocked, the spread of infectious diseases can be effectively prevented.

Aerosol generating procedures must be performed in a singlechaired, closed operatory with minimal items in the display when possible. ${ }^{29}$ In dental practices or teaching institutions with multiple chair open layout, the recommended distance between 2 chairs is 6 feet $^{51,53}$ but researches demonstrate an unacceptable increase in bacterial load and distances covered by aerosols generated in such settings. Easy to clean, floor to ceiling physical barriers between dental chairs are advised by the CDC for multiple chair dental setups (Fig. 2). ${ }^{51}$

\section{Environmental Controls}

Many environmental factors such as temperature, humidity, and airflow influence the viability and the fate of an airborne infectious agent.

\section{Ventilation}

Li et al., in their review on the transmission of infectious diseases found strong evidence between aerosol transmission and ventilation correlation. ${ }^{2}$ Dilution and extraction ventilation, pressurization, airflow distribution and optimization, mechanical filtration, ultraviolet germicidal irradiation (UVGI), and humidity control are effective strategies for reducing the risk of dissemination of infectious aerosols. ${ }^{54}$

Mixing of the contaminated room air with uncontaminated air breaks the pockets of concentrated droplet nuclei. Eventually, the concentration of the contaminant in the room air will increase until the source is removed.

Dilution of the airborne contaminants with fresh air using natural (windows and doors), hybrid ventilation, or a heating ventilation and air conditioning (HVAC) system by increasing the air changes per hour $(\mathrm{ACH})$ can greatly reduce the risk of indoor airborne transmission. Recommended $\mathrm{ACH}$ for the treatment room is a minimum of 6 to $12^{20}$ and should be compatible with the occupancy and the equipment in the room. ${ }^{51}$

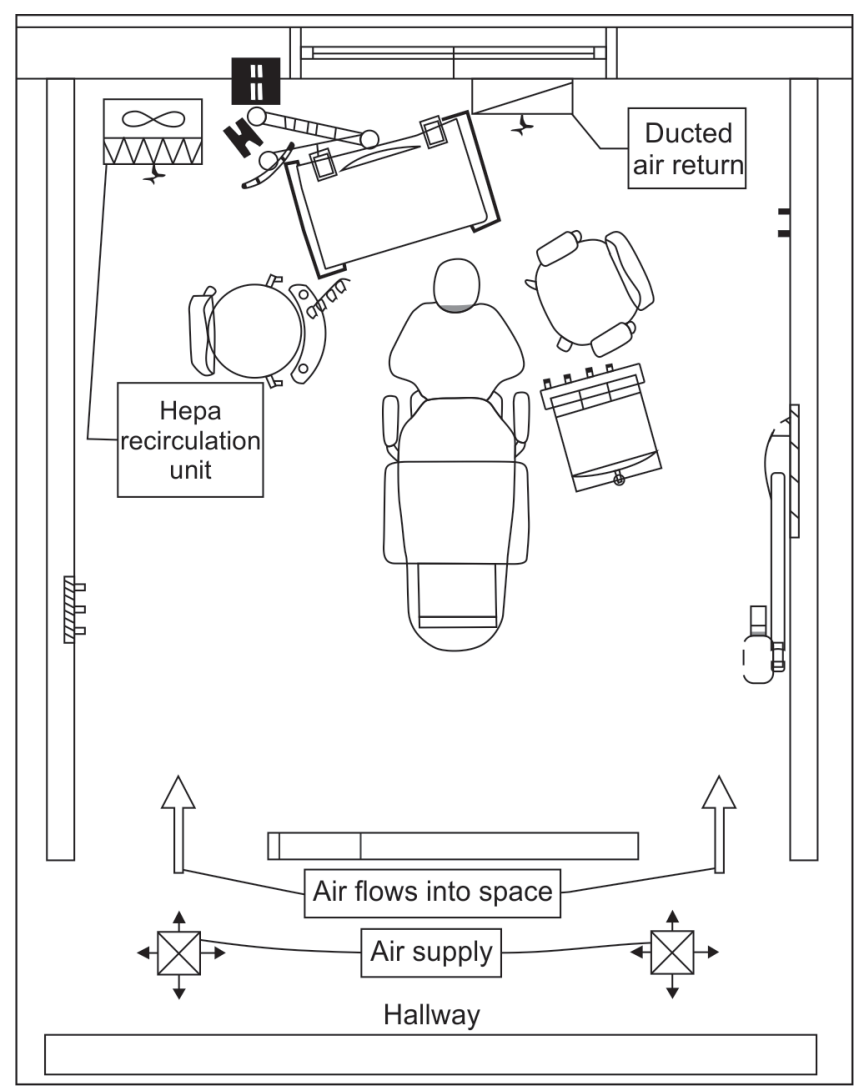

Fig. 2: Recommended dental setup blueprint given by CDC/NIOSH

\section{Direction of Air Flow and Air Cleaning Strategies}

The fresh air from the corridor should flow into the room, towards the DHCP and then the patient, and get exhausted to the outside. Slight changes in the natural airflow, temperature, or pressure differential might affect the direction of airflow. Better control over airflow can be achieved by careful positioning of the inlet vent in clean areas and the outlet exhaust in the dirty area closer to the patient. ${ }^{51}$ The CDC recommends the treatment of a known case of airborne infectious transmissible disease to be done in an airborne infection isolation room (AIIR) or a negatively pressurized chamber. ${ }^{1}$ Negative pressure rooms are fitted with ventilation modules capable of maintaining a pressure differential of $2.5 \mathrm{~Pa}$ ( 0.01 inch of water gauge). This ensures the airflow rate into the room is less than the exhaust flow rate to ensure the complete removal of airborne contaminants from the room. ${ }^{20,55}$

Filtration of the room air can effectively reduce airborne contaminants. A centralized HVAC system with an inbuilt highefficiency particulate filter (HEPA 14) efficiently reduces the transport of airborne infectious agents in recirculated air. ${ }^{56}$ Carefully selected and strategically placed single space HEPA filters (ceiling mount or portable) with CADR of 300-800 feet ${ }^{3} /$ minute, capable of achieving minimum $12 \mathrm{ACH}$ can effectively reduce the airborne infectious load within a closed space and concurrently achieve directional airflow. ${ }^{20,55}$ Although the evidence on the effect of air purification in the dental setting is limited, ${ }^{57,58}$ the $C D C$ recommends the use of portable HEPA filters (Fig. 3). ${ }^{51}$

Disinfection of the room air with (UVGI) of the Far-UVC energy range of $200-280 \mathrm{~nm}$ is the most germicidal and relatively safe. Most of the commercially available UVGI bulbs produce an optimum wavelength of $254 \mathrm{~nm}$, which kills the microorganisms in the air by 


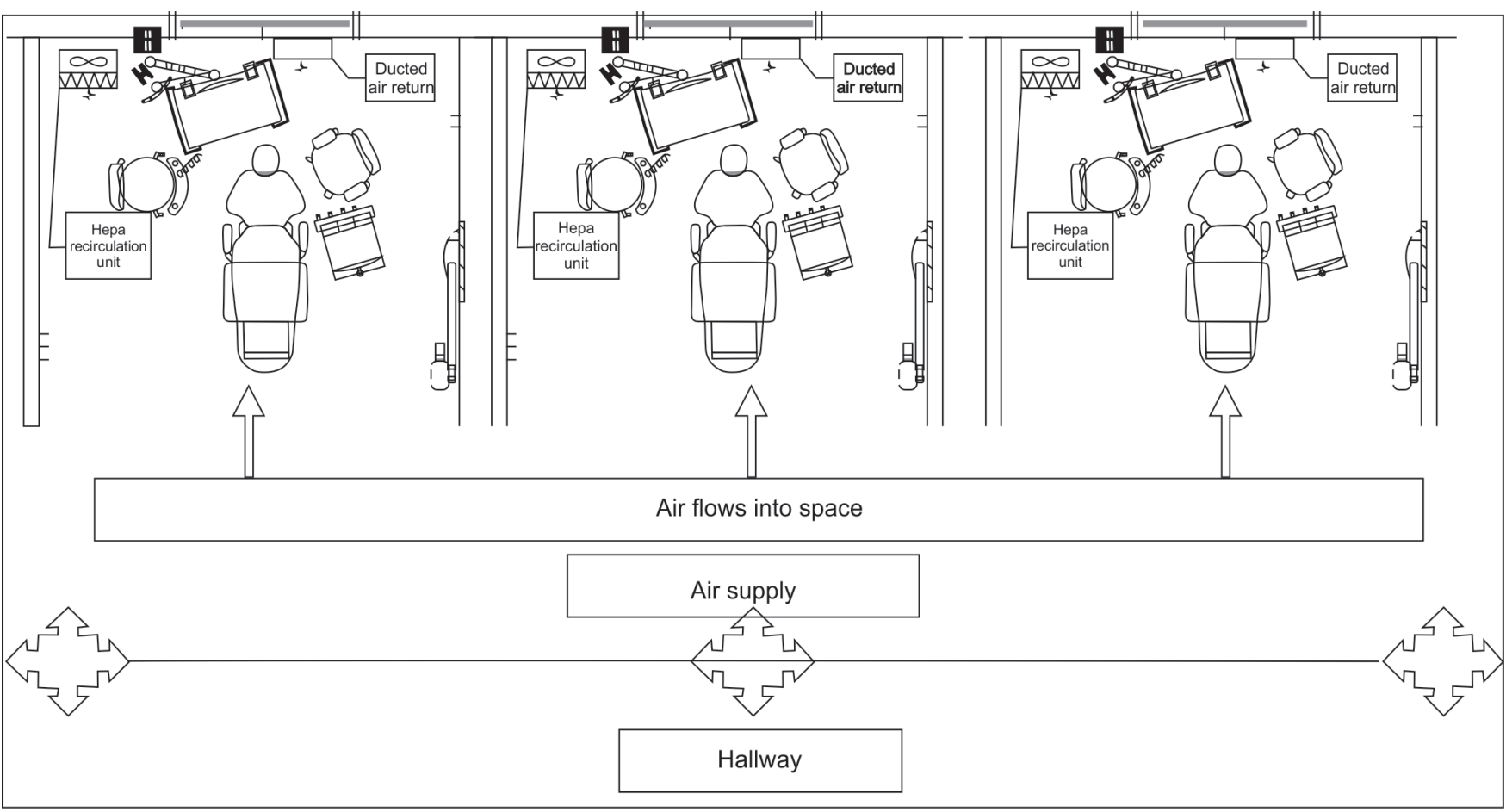

Fig. 3: Recommended design for multiple-chair open layout. Ensure there is at least 6 feet of space between patient chairs. Place physical barriers between patient chairs. Orient operatories parallel to the direction of airflow if possible

denaturing nucleic acid and proteins. The CDC interim guidelines during COVID-19 recommends the use of upper-room UVGI as an adjunct to improved air exchange and filtration. ${ }^{54,55}$

\section{Temperature and Humidity}

Ambient relative humidity $(\mathrm{RH})$ can influence infectivity and spread of certain airborne infections like influenza. ${ }^{54,59}$ Maintaining mid-range humidity levels of $40-60 \%$ indoor is reported to be the most detrimental to the survival of many microorganisms. Immunobiologists report RH levels below $40 \%$ increase the risk for disease by three folds, firstly by favoring the formation of droplet nuclei that remain airborne, secondly many viruses and bacteria are anhydrous resistant, and hence survive better at a lower relative humidity ${ }^{60,61}$ and finally, $\mathrm{RH}$ below $40 \%$ is known to impair mucous membrane barrier and immune response. ${ }^{62}$ Maintaining $\mathrm{RH}$ in low temperatures might run the risk of condensation and mold growth.

\section{Conclusion}

Currently, no evidence directly points to the spread of infectious diseases due to aerosols generated during the dental procedures, but the risk cannot be ignored. A suggested guideline for permissible microbial air contamination of hospital wards, surgeries, and operation theaters exists. ${ }^{63}$ No such guidelines for dental setting exits. Most dental practices are isolated individual practice offering outpatient, ambulatory care, which lack epidemiologist or hospital infection control experts to monitor and track nosocomial infections. The recommendations and guidelines for safe dental practices are predominantly based on healthcare precedent, theoretical rationale, and expert opinion. Dental literature still lacks epidemiological surveys that accurately report occupationrelated morbidity and mortality among the DHCP. In the absence of such data, it is only reasonable for the DHCP to adopt necessary precautions to ensure safe dental practice.

\section{Acknowledgment}

The authors thank Dr Krithika Datta for her support and encouragement in writing this review article.

\section{References}

1. Kohn WG, Collins AS, Cleveland JL, et al. Guidelines for infection control in dental health-care settings--2003. MMWR Recomm Rep Morb Mortal Wkly Rep Recomm Rep 2003;52(RR-17):1-61.

2. Li Y, Leung GM, Tang JW, et al. Role of ventilation in airborne transmission of infectious agents in the built environment a multidisciplinary systematic review. Indoor Air 2007;17(1):2-18. DOI: 10.1111/j.1600-0668.2006.00445.x.

3. Roy CJ, Milton DK. Airborne transmission of communicable infectionthe elusive pathway. N Engl J Med 2004;350(17):1710-1712.

4. WHO, Infection prevention and control of epidemic- and pandemicprone acute respiratory infections in health care [Internet]. World Health Organization; 2014 [cited 2020 Jul 1]. Available from: https:// apps.who.int/iris/handle/10665/112656.

5. Stadtländer CTK-H. Control of Communicable Diseases Manual Heymann DL, ed. 18th ed., Washington DC, USA: American Public Health Association; 2004. pp. 700. , US \$33.00. ISBN: 0-87553-034-6 Int J Epidemiol. 2005;34(6):1446-7.

6. Goldmann DA. Epidemiology and prevention of pediatric viral respiratory infections in health-care institutions. Emerg Infect Dis 2001;7(2):249-253. DOI: 10.3201/eid0702.010220.

7. Yu ITS, Li Y, Wong TW, et al. Evidence of airborne transmission of the severe acute respiratory syndrome virus. N Engl J Med 2004;350(17):1731-1739. DOI: 10.1056/NEJMoa032867.

8. Miller RL, Micik RE, Abel C, et al. Studies on dental aerobiology: II. Microbial splatter discharged from the oral cavity of dental patients. J Dent Res 1971;50(3):621-625. DOI: 10.1177/00220345710500031701. 
9. Centers for Disease Control (CDC). Guidelines for prevention of transmission of human immunodeficiency virus and hepatitis $B$ virus to health-care and public-safety workers. MMWR Suppl 1989;38(6): 1-37.

10. Aerosol Technology: Properties, Behavior, and Measurement of Airborne Particles, 2nd Edition | Wiley [Internet]. Wiley.com. [cited $2020 \mathrm{Jul}$ 1]. Available from: https://www.wiley.com/enin/Aerosol+T echnology $\% 3 \mathrm{~A}+$ Properties $\% 2 \mathrm{C}+$ Behavior $\% 2 \mathrm{C}+$ and + Measuremen $\mathrm{t}+$ of+Airborne+Particles\%2C+2nd+Edition-p-9780471194101.

11. Tellier R, Li Y, Cowling BJ, et al. Recognition of aerosol transmission of infectious agents: a commentary. BMC Infect Dis 2019;19(1):101. DOI: 10.1186/s12879-019-3707-y.

12. Keene $\mathrm{CH}$. Airborne contagion and air hygiene. William firth wells. J Sch Health 1955;25(9):249-249. DOI: 10.1111/j.1746-1561.1955. tb08015.x.

13. Feigin RD, Baker CJ, Herwaldt LA, et al. Epidemic meningococcal disease in an elementary-school classroom. N Engl J Med 1982;307(20):1255-1257. DOI: 10.1056/NEJM198211113072007.

14. DickEC, Jennings $L C$, MinkKA, et al. Aerosol transmission of rhinovirus colds. J Infect Dis 1987;156(3):442-448. DOI: 10.1093/infdis/156.3.442.

15. Wong T, Lee C, Tam W, est al. Cluster of SARS among medical students exposed to single patient, Hong Kong. Emerg Infect Dis 2004;10(2):269-276. DOI: 10.3201/eid1002.030452.

16. Little JW, Douglas RG, Hall WJ, et al. Attenuated influenza produced by experimental intranasal inoculation. J Med Virol 1979;3(3):177-188. DOI: $10.1002 / j m v .1890030303$.

17. Cowling BJ, Ip DKM, Fang VJ, et al. Aerosol transmission is an important mode of influenza A virus spread. Nat Commun 2013;4(1):1935. DOI: 10.1038/ncomms2922.

18. Riley RL. Airborne infection. Am J Med 1974;57(3):466-475. DOI: 10.1016/0002-9343(74)90140-5.

19. Knight V. Viruses as agents of airborne contagion. Ann N Y Acad Sci 1980;353(1):147-156. DOI: 10.1111/j.1749-6632.1980.tb18917.x.

20. Tang JW, LiY, Eames l, et al. Factors involved in the aerosol transmission of infection and control of ventilation in healthcare premises. J Hosp Infect 2006;64(2):100-114. DOI: 10.1016/j.jhin.2006.05.022.

21. Micik RE, Miller RL, Mazzarella MA, et al. Studies on dental aerobiology: I. Bacterial aerosols generated during dental procedures. J Dent Res 1969;48(1):49-56. DOI: 10.1177/00220345690480012401.

22. Micik RE, Miller RL, Leong AC. Studies on dental aerobiology: III. Efficacy of surgical masks in protecting dental personnel from airborne bacterial particles. J Dent Res 1971;50(3):626-630. DOI: 10.1177/00220345710500031801.

23. Belting CM, Haberfelde GC, JuhI LK. Spread of organisms from dental air rotor. J Am Dent Assoc 1939 1964;68(5):648-651. DOI: 10.14219/ jada.archive.1964.0145

24. Bentley CD, Burkhart NW, Crawford JJ. Evaluating spatter and aerosol contamination during dental procedures. J Am Dent Assoc 1994;125(5):579-584. DOI: 10.14219/jada.archive.1994.0093.

25. Cole EC, Cook CE. Characterization of infectious aerosols in health care facilities: an aid to effective engineering controls and preventive strategies. Am J Infect Control 1998;26(4):453-464. DOI: 10.1016/ S0196-6553(98)70046-X.

26. Bennett JE, Dolin R, Blaser MJ, Mandell, Douglas, and Bennett's Principles and Practice of Infectious Diseases [Internet]. Elsevier Inc.; 2014 [cited $2020 \mathrm{Jul}$ 1]. Available from: https://jhu.pure.elsevier.com/ en/publications/mandell-douglas-and-bennetts-principles-andpractice-of-infectiou.

27. Al Maghlouth A, Al Yousef $\mathrm{Y}, \mathrm{Al}$-Bagieh NH. Qualitative and quantitative analysis of microbial aerosols in selected areas within the college of dentistry, King Saud University. Quintessence Int Berl Ger 1985 2007;38(5):e222-e228.

28. Kimmerle H, Wiedmann-Al-Ahmad M, Pelz K, et al. Airborne microbes in different dental environments in comparison to a public area. Arch Oral Biol 2012;57(6):689-696. DOI: 10.1016/j.archoralbio.2011.11.012.

29. Rautemaa R, Nordberg A, Wuolijoki-Saaristo K, et al. Bacterial aerosols in dental practice - a potential hospital infection problem? J Hosp Infect 2006;64(1):76-81. DOI: 10.1016/j.jhin.2006.04.011.
30. Grenier D. Quantitative analysis of bacterial aerosols in two different dental clinic environments. Appl Environ Microbiol 1995;61(8): 3165-3168. DOI: 10.1128/AEM.61.8.3165-3168.1995.

31. Epstein JB, Rea G, Sibau L, et al. Assessing viral retention and elimination in rotary dental instruments. J Am Dent Assoc 1939 1995;126(1):87-92. DOI: 10.14219/jada.archive.1995.0028.

32. Lewis $\mathrm{DL}$, Arens $\mathrm{M}$, Suzuki M, et al. Cross-contamination potential with dental equipment. Lancet Lond Engl 1992;340(8830):1252-1254. DOI: 10.1016/0140-6736(92)92950-K.

33. Lewis DL, Boe RK. Cross-infection risks associated with current procedures for using high-speed dental handpieces. J Clin Microbiol 1992;30(2):401-406. DOI: 10.1128/JCM.30.2.401-406.1992.

34. Barnes JB, Harrel SK, Rivera-Hidalgo F. Blood contamination of the aerosols produced by in vivo use of ultrasonic scalers. J Periodontol 1998;69(4):434-438. DOI: 10.1902/jop.1998.69.4.434.

35. Legnani P, Checchi L, Pelliccioni GA, et al. Atmospheric contamination during dental procedures. Quintessence Int Berl Ger 1985 1994;25(6):435-439.

36. Gross KB, Overman PR, Cobb C, et al. Aerosol generation by two ultrasonic scalers and one sonic scaler. A comparative study. J Dent Hyg JDH 1992;66(7):314-318.

37. Basu MK, Browne RM, Potts AJ, et al. A survey of aerosol-related symptoms in dental hygienists. J Soc Occup Med 1988;38(1-2):23-25. DOI: 10.1093/occmed/38.1-2.23.

38. Ricci ML, Fontana S, Pinci F, et al. Pneumonia associated with a dental unit waterline. Lancet Lond Engl 2012;379(9816):684. DOI: 10.1016/ S0140-6736(12)60074-9.

39. Pankhurst CL, Coulter W, Philpott-Howard JN, et al. Evaluation of the potential risk of occupational asthma in dentists exposed to contaminated dental unit waterlines. Prim Dent Care J Fac Gen Dent Pract UK 2005;12(2):53-59. DOI: 10.1308/1355761053695176.

40. Reinthaler FF, Mascher F, Stünzner D. Serological examinations for antibodies against Legionella species in dental personnel. J Dent Res 1988;67(6):942-943. DOI: 10.1177/00220345880670061001.

41. Zemouri C, Volgenant CMC, Buijs MJ, et al. Dental aerosols: microbial composition and spatial distribution. J Oral Microbiol 2020;12(1):1762040. DOI: 10.1080/20002297.2020.1762040.

42. Polednik B. Aerosol and bioaerosol particles in a dental office. Environ Res 2014;134:405-409. DOI: 10.1016/j.envres.2014.06.027.

43. Samaranayake LP, Reid J, Evans $D$. The efficacy of rubber dam isolation in reducing atmospheric bacterial contamination. ASDC J Dent Child 1989;56(6):442-444.

44. Harrel SK, Barnes JB, Rivera-Hidalgo F. Aerosol reduction during air polishing. Quintessence Int Berl Ger 1985 1999;30(9):623-628.

45. Muzzin KB, King TB, Berry CW. Assessing the clinical effectiveness of an aerosol reduction device for the air polisher. J Am Dent Assoc 1939 1999;130(9):1354-1359. DOI: 10.14219/jada.archive.1999. 0407.

46. Kohn WG, Harte JA, Malvitz DM, et al. Cover story guidelines for infection control in dental health care settings-2003. J Am Dent Assoc 2004;135(1):33-47. DOI: 10.14219/jada.archive.2004.0019.

47. Ceisel RJ, Osetek EM, Turner DW, et al. Evaluating chemical inactivation of viral agents in handpiece splatter. J Am Dent Assoc 1939 1995;126(2):197-202. DOI: 10.14219/jada.archive.1995.0145.

48. Grayson BH, Li WKP, Benjaminson MA. Viability of bacteria in high-speed dental drill aerosols with antimicrobial agents in the water coolant system. J Dent Res 1973;52(1):7-12. DOI: $10.1177 / 00220345730520013801$.

49. Fine $\mathrm{DH}$, Yip J, Furgang D, et al. Reducing bacteria in dental aerosols: pre-procedural use of an antiseptic mouthrinse. J Am Dent Assoc 1939 1993;124(5):56-58. DOI: 10.14219/jada.archive.1993.0122.

50. Molinari JA, Molinari GE. Is mouthrinsing before dental procedures worthwhile? J Am Dent Assoc 1939 1992;123(3):75-80. DOI: 10.14219/ jada.archive.1992.0079.

51. CDC. Coronavirus Disease 2019 (COVID-19) [Internet]. Centers for Disease Control and Prevention. 2020 [cited 2020 Mar 19]. Available from: https://www.cdc.gov/coronavirus/2019-ncov/infectioncontrol/control-recommendations.html. 
52. Bennett AM, Fulford MR, Walker JT, et al. Microbial aerosols in general dental practice. Occup Health (Lond) 2000;189(12):4. DOI: 10.1038/ sj.bdj.4800859.

53. Vilarinho Oliveira AMA, de Alencar RM, Santos Porto JC, et al. Analysis of fungi in aerosols dispersed by high speed pens in dental clinics from Teresina, Piaui, Brazil. Environ Monit Assess 2018;190(2):56. DOI: 10.1007/s10661-017-6436-y.

54. Stewart EJ, Schoen LJ, Mead K, et al. ASHRAE Position Document on Infectious Aerosols. 2020. 24.

55. Disinfection \& Sterilization Guidelines |Guidelines Library|Infection Control | CDC [Internet]. 2019 [cited 2020 Mar 19]. Available from: https://www.cdc.gov/infectioncontrol/guidelines/disinfection/ index.html.

56. Azimi P, Stephens B. HVAC filtration for controlling infectious airborne disease transmission in indoor environments: predicting risk reductions and operational costs. Build Environ 2013;70:150-160. DOI: 10.1016/j.buildenv.2013.08.025.

57. Hallier C, Williams DW, Potts AJC, et al. A pilot study of bioaerosol reduction using an air cleaning system during dental procedures. $\mathrm{Br}$ Dent J 2010;209(8):E14-E14. DOI: 10.1038/sj.bdj.2010.975.

58. Chen C, Zhao B, Cui W, et al. The effectiveness of an air cleaner in controlling droplet/aerosol particle dispersion emitted from a patient's mouth in the indoor environment of dental clinics. J R Soc Interface 2010;7(48):1105-1118. DOI: 10.1098/rsif.2009. 0516.

59. Derby MM, Hamehkasi M, Eckels $S$, et al. Update of the scientific evidence for specifying lower limit relative humidity levels for comfort, health, and indoor environmental quality in occupied spaces (RP-1630). Sci Technol Built Environ 2017;23(1):30-45. DOI: 10.1080/23744731.2016.1206430.

60. de Goffau MC, Yang X, van Dijl JM, et al. Bacterial pleomorphism and competition in a relative humidity gradient. Environ Microbiol 2009;11(4):809-822. DOI: 10.1111/j.1462-2920.2008.01802.x.

61. Kudo E, Song E, Yockey LJ, et al. Low ambient humidity impairs barrier function and innate resistance against influenza infection. Proc Natl Acad Sci USA 2019;116(22):10905-10910. DOI: 10.1073/ pnas. 1902840116.

62. Stone W, Kroukamp O, Korber DR, et al. Microbes at Surface-air interfaces: the metabolic harnessing of relative humidity, surface hygroscopicity, and oligotrophy for resilience. Front Microbiol 2016;7:1563. DOI: 10.3389/fmicb.2016.01563.

63. Fischer $G$, Fodré $S$, Nehéz $M$. Results of the study to determine marginal pathogen count values in the air of operating rooms. Z Gesamte Hyg 1972;18(10):729-733. 